\title{
Microwave-accelerated Solvent and Catalyst Free Synthesis of 3-Indolylhydroquinones
}

\author{
J. S. Yadav, B. V. Subba Reddy, K. Shiva Shankar, T. Swamy, and K. Premalatha \\ Diwision of Organic Chemistry, Indian Institute of Chemical Technolog, Hyderabad-500007, India \\ E-mail: vadapubainctresin \\ Received September 28, 2007
}

Key Words : Conjugate addition. Indoles. $p$-Quinones. Microwave irradiation. 3-Indoly lhỵdroquinones

The 3-indolylbenzoquinone nucleus is present in various biologically active natural products such as asterriquinones. ${ }^{1}$ The asterriquinones and demethylasterriquinones (Figure 1) have recently been isolated from a wide range of fungi. including Aspergillus terreus. Chaetomium sp. and Pseudomassaria sp..$^{2}$ They exhibit a wide spectrun of biological activities including antitumor properties and are inhibitors of HIV reverse transcriptase. ${ }^{3}$ Asterriquinone $\mathrm{Al}$ has been shown to arrest the cell cycle in Gl and promote apoptotic cell death ${ }^{4}$ Recently, asterriquinone has also been reported as an orally active non-peptidyl mimetic of insulin with antidiabetic activity. All these properties apparently stem from the ability of asterriquinones to either promote or prevent protein-protein interactions.

The direct method for the synthesis of 3-indolylhydroquinones involves the condensation of $p$-quinones with indoles under acidic conditions. ${ }^{6}$ In spite of their wide range of phannacological activities; the synthesis of 3-indolylhydroquinones has recejved little attention. Therefore. the development of a rapid and efficient protocol for the synthesis of 3-indolylhydroquinone scaffolds is desirable.

Recently. microwave irradiation has becone a powerful technique in organic synthesis. which is being increasingly used to accelerate the organic reactions. Microwave assisted organic synthesis (MAOS) have a significant impact on synthetic organic chemistry especially those reactions under solvent free conditions with the remarkable merits of reduced reaction time. improved yields, suppressed side reactions. decreased environmental pollution and safe operations. ${ }^{7}$ Thus, microwave irradiation has become a powerful tool for the rapid synthesis of a variety of organic molecules under solvent-free conditions. ${ }^{8}$ However, there are no
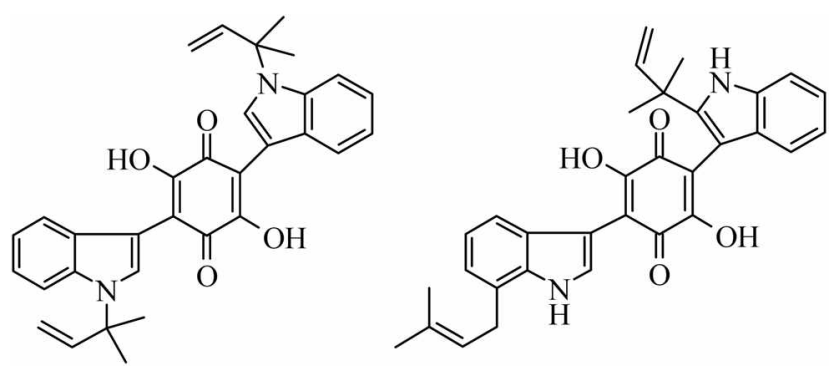

Asterriquinone $\mathrm{A} 1$

L-783,281, Demethylasterriquinone B1

Figure 1 reports on the conjugate addition of indoles to $p$-quinones employing microwave irradiation.

In this article, we wish to report a rapid, convenient and efficient microwave assisted reaction for the synthesis of various 3-indolylhydroquinone derivatives under solventfree conditions. Initially. 1,4-naphthoquinone (1) was treated with indole (2) under microwave irradiation. The reaction completed in $45 \mathrm{sec}$ and the product. 2-(lH-indol-3-yl)naphthalene-1.4-diol 3a was obtained in $94 \%$ yield (Scheme 1).

Similarly, 1.4-naphthoquinone reacted rapidly with 2methylindole to give 2-(2-methyl-l $H$-indol-3-yl)naphthalene-1,4-diol in $90 \%$ yield (Table 1. entry $3 \mathbf{b}$ ). Interestingly, 2-methyl substituted 1.4-naphthoquinone reacted readily with indole and 2-methylindole to furnish the corresponding indolyl-naphthalene-1,4-diols in excellent yields (Table 1 . entries $3 c$ and $d$ ). The reaction of $p$-benzoquinone with indole, 2-methylindole and 2-ethoxycarbonyl indole also gave 1.4-hydroquinone derivatives in good yields (Table 1 , entries 3e-g). Similarly, substituted $p$-quinones reacted smoothly with various indoles to produce the respective hydroquinone derivatives in high yields (Table 1). Quinones having methyl groups adjacent to unsaturated positions. like 2-methyl-1,4-benzoquinone and 2-methoxy-1.4-benzoquinone reacted effectively with indoles to afford 3-indolylhydroquinones at the unsubstituted ring site (entries $3 \mathbf{h}-\mathbf{j}$ ). Disubstituted quinones such as 2,6-dimethylbenzoquinone and 2.5-dichlorobenzoquinone also reacted smoothly with indoles to produce the corresponding 3-indolylhydroquinones in high yields (entries $\mathbf{3 k}-\mathbf{q}$, Scheme 2).

In all the cases, reactions proceeded rapidly without the need of a catalyst. The reactions were clean and the products were obtained in excellent yields. To know the efficiency of this procedure. the reactions were carried out both under microwave as well as thermal conditions. Interestingly. the reactions proceeded rapidly under microwave irradiation in

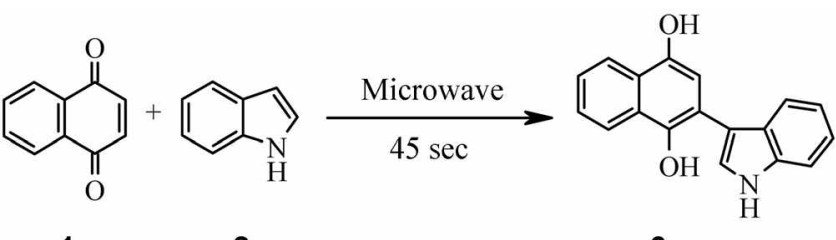

1

2
$3 \mathbf{a}$

Scheme 1 
Table 1. Adition of indoles to $p$-quinones promoted by microwave

\begin{tabular}{|c|c|c|c|c|c|}
\hline Entry & Quinone (1) & Indole (2) & $\begin{array}{c}\text { Product } \\
(\mathbf{3})^{4}\end{array}$ & $\begin{array}{l}\text { Time } \\
(\sec )^{b}\end{array}$ & $\begin{array}{l}\text { Yield } \\
(\%)^{c}\end{array}$ \\
\hline a & & & $3 a$ & 45 & 94 \\
\hline b & & & $3 b$ & 45 & 90 \\
\hline$c$ & & & $3 c$ & 45 & 92 \\
\hline $\mathrm{d}$ & & & $3 d$ & 45 & 87 \\
\hline e & & & $3 e$ & 60 & 85 \\
\hline f & " & & $3 f$ & 60 & 80 \\
\hline g & $"$ & & $3 g$ & 80 & 75 \\
\hline h & & & $3 \mathrm{~h}$ & 50 & 85 \\
\hline 1 & " & & $3 i$ & 50 & 80 \\
\hline 1 & & & $3 \mathbf{j}$ & 60 & 85 \\
\hline $\mathrm{k}$ & & & $3 \mathrm{k}$ & 50 & 90 \\
\hline 1 & $"$ & & 31 & 50 & 85 \\
\hline $\mathrm{m}$ & & & $3 m$ & 60 & 85 \\
\hline n & " & & $3 n$ & 70 & 83 \\
\hline 0 & * & & 30 & 65 & 85 \\
\hline $\mathrm{p}$ & 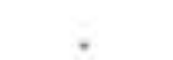 & & $3 p$ & 70 & 85 \\
\hline$q$ & * & & 34 & 80 & 79 \\
\hline
\end{tabular}

"All products were characterized by 'H NMR. IR and mass spectroscopy. ${ }^{6} \mathrm{Microwave}$ irtadiation was carried out at 450 Watts using BPL. BMO, 7001 domestic micronare oven. "Yield refers to pure products after chromatography.

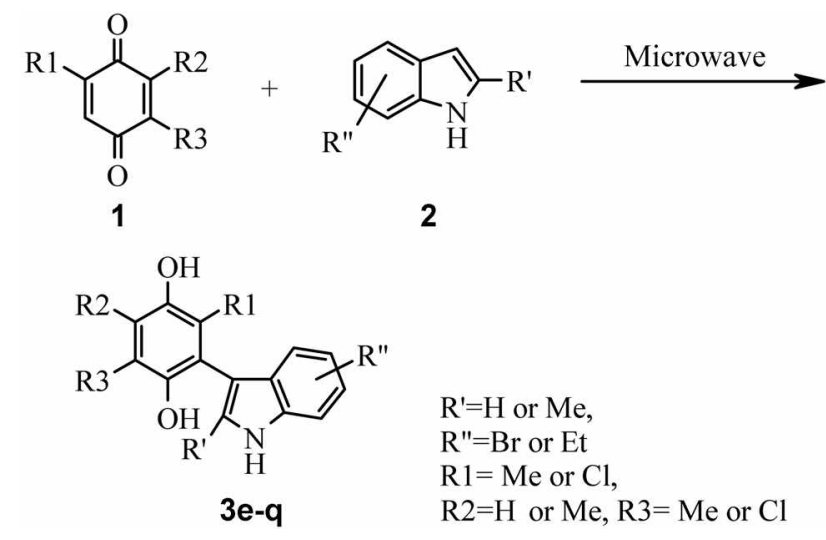

Scheme 2

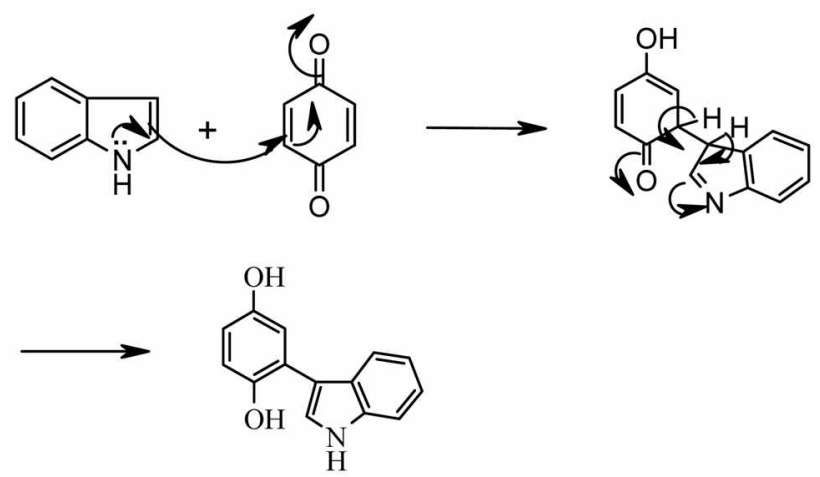

Scheme 3

solvent-free conditions. The reaction temperature was controlled by using a pulsed irradiation technique ( $40 \mathrm{sec}$ with $10 \mathrm{~s}$ intervals). The temperature was measured after each pulse. The lowest observed temperature was $70^{\circ} \mathrm{C}$ after irradiation for $40 \mathrm{sec}$ at $450 \mathrm{~W}$ and the highest temperature was $90^{\circ} \mathrm{C}$ after $2 \mathrm{~min}$ irradiation at the same power. The reaction rates and yields were significantly enhanced by microwave irradiation. The rate enhancement under microwave irradiation may be attributed to the absorption of more microwave energy by the polar substrates. which generates sufficient heat energy to promote the reaction. The same reaction. under thermal conditions. at $90^{\circ} \mathrm{C}$. took $2-3 \mathrm{~h}$ to afford comparable yields those that are obtained by microwave irradiation. The probable mechanism could be the addition of indole to the unsaturated position of the $p$ quinone. which might be getting activated by microwave irradiation (Scheme 3).

This method is clean and free from the chlorinated side products which are usually observed under protic acid (conc. $\mathrm{HCl}$ in THF) conditions. This method also works well with the electron-deficient 2-ethoxycarbonyl indole to give the corresponding 3-indolylhydroquinone $\mathbf{3 g}$ in fairly good yield. However. most of the reported methods fail to produce 3-indolylhydroquinones with electron-deficient indoles. Thus. this method is an efficient and useful alternative for the syinthesis of the core structures of natural products. The scope and generality of this process is illustrated with respect to various indoles and a wide range of $p$-quinones and the results are presented in Table 1. 


\section{Conclusion}

In summary, we have described a rapid and highly efficient protocol for the preparation of 3-indoly lhydroquinones by means of nucleophilic addition of indoles to $p$-quinones using microwave irradiation. This method is applicable to both electron-rich as well as electron-deficient indoles and can be applied to the total synthesis of naturally occurring asterriquinones. The present method avoids high temperature reaction conditions. extended reaction times and the use of solvent and catalyst. The time saving ability together with very short response times and the minimization of thermal decomposition of products are the main advantages of microwave heating over classical methods.

\section{Experimental Section}

Melting points were recorded on Buchi R-535 apparatus and are uncorrected. IR spectra were recorded on a PerkinElmer FT-IR 240-c spectrophotometer using $\mathrm{KBr}$ optics. ${ }^{1} \mathrm{H}$ NMR spectra were recorded on Gemini-200 spectrometer in $\mathrm{CDCl}_{3}$ using TMS as internal standard. Mass spectra were recorded on a Finnigan MAT 1020 mass spectrometer operating at $70 \mathrm{eV}$. TLC was monitored on $0.25 \mathrm{~mm}$ precoated silica gel plates $(60 \mathrm{~F}-254)$. BPL, BMO-800 $\mathrm{T}$ domestic microwave oven was used to perform the reactions.

General procedure for the 3-indolylhydroquinones. A mixture of the $p$-quinone $(1 \mathrm{mmol}$ ) and indole ( $1 \mathrm{mmol}$ ) was subjected to microwave irradiation. operating at 450 Watts using BPL, BMO-800 T microwave oven, for the appropriate time (Table 1). After complete conversion, as indicated by TLC, the residue was dissolved in ethyl acetate $(10 \mathrm{~mL})$ and concentrated in vacuo. Then the resulting crude product was purified by column chromatography using ethyl acetatehexane mixture as eluent to afford pure 3-indolylhydroquinones. The products thus obtained were characterized by comparison of their NMR. IR. mass. TLC, mixed TLC analysis and physical data with authentic samples?

Spectroscopic data for selected compounds:

3a: 2-(1H-Indol-3-yl)naphthalene-1,4-diol: Solid. m.p: $185-187^{\circ} \mathrm{C} ;{ }^{1} \mathrm{H}$ NMR $\left(200 \mathrm{MHz} . \mathrm{CDCl}_{3}\right): \delta 6.95$ (s, IH). 7.20-7.25 (m. 2H) . 7.35-7.40 (m. 1H). 7.65-7.75 (m. 4H). $8.05-8.10$ (m. 2H). 8.60 (brs. 1H. NH): ${ }^{13} \mathrm{C}$ NMR (50 MHz. $\left.\mathrm{CDCl}_{3}\right): \delta 101.5 .103 .2,108.0,112.0 .119 .2 .120 .5,122.0$. 122.5. 123.1. 124.3, 125.6, 126.4. 127.8, 128.0, 130.5 . 134.0. 146.0. 147.2: IR (KBr): $v_{\max } 3452,2936,1617,1457$. 1219. $1015,850.772 \mathrm{~cm}^{-1}$; ESI-MS: $m / z: 276\left(\mathrm{M}^{+}+1\right)$.

3f: 2-(2-Methyl-1H-indol-3-yl)benzene-1,t-diol: Solid. mp: $106-108{ }^{\circ} \mathrm{C}:{ }^{1} \mathrm{H}$ NMR $\left(\mathrm{CDCl}_{3}\right): 2.40$ (s. $\left.3 \mathrm{H}\right), 4.40$ (brs. 1H. OH), 4.60 (brs. $1 \mathrm{H}, \mathrm{OH}), 6.70-6.80(\mathrm{~m}, 2 \mathrm{H}), 6.90$ (d. lH. $J=8.0 \mathrm{~Hz}$ ). $7.05-7.20(\mathrm{~m}, 2 \mathrm{H}) .7 .30-7.45(\mathrm{~m} .2 \mathrm{H}) .8 .0$ (brs. $1 \mathrm{H}, \mathrm{NH}):{ }^{13} \mathrm{C}$ NMR $\left(50 \mathrm{MHz}, \mathrm{CDCl}_{3}\right.$ ): $12.9,109.9$. 110.8. 114.3. 116.1. 116.8, 118.3, 118.9. 120.5. 122.9. 128.3, 133.3. 135.6, 147.8, 149.8: IR (KBr): $v_{\text {max }} 3279,2923$. 1636. $1565,1457.1294,1010.774 \mathrm{~cm}^{-1}$ : ESI-MS: $m / z: 240$ $\left(\mathrm{M}^{+}+1\right)$.

3I: 3,5-Dimethyl-2-(2-methyl-1H-indol-3-yl)benzene- 1,4-diol: Solid. m.p: 85-86 ${ }^{\circ} \mathrm{C}:{ }^{1} \mathrm{H} N M R\left(200 \mathrm{MHz}, \mathrm{CDCl}_{3}\right)$ : $\delta 2.0(\mathrm{~s}, 3 \mathrm{H}), 2.20(\mathrm{~s}, 3 \mathrm{H}), 2.30(\mathrm{~s} .3 \mathrm{H}) .6 .70(\mathrm{~s} . \mathrm{HH}) .7 .05 \cdot$ $7.20(\mathrm{~m}, 2 \mathrm{H}) .7 .25-7.30(\mathrm{~m}, 2 \mathrm{H}), 8.10(\mathrm{brs}, \mathrm{lH}, \mathrm{NH}),{ }^{12} \mathrm{C}$ NMR (50 MHz. $\mathrm{CDCl}_{3}$ ): $10.8,13.2,14.5 .108 .6,111.2$, $116.2,118.4$. 119.5. 120.5, 122.6. 127.3, 128.2. 129.8, 133.1. 136.6, 147.7. 149.5: IR (KBr): $v_{\text {nax }} 3415.2927 .1521,1376$, 1263. 1055. 820, $772 \mathrm{~cm}^{-1}$. ESI-MS: $m / z: 268\left(\mathrm{M}^{-}+1\right)$.

3m: 2,5-Dichloro-3-(1 H-indoI-3-yl)benzene-1,4-diol: Solid. m.p: $81-82{ }^{\circ} \mathrm{C} ;{ }^{1} \mathrm{H}$ NMR $\left(200 \mathrm{MHz}, \mathrm{CDCl}_{3}\right): \delta 5.15$ (brs, 1H. OH). 5.30 (brs, 1H. OH). 7.05 (d, $J=1.9 \mathrm{~Hz} . \mathrm{lH}$ ), $7.10-7.35$ (m. $5 \mathrm{H}$ ), 8.70 (brs. $1 \mathrm{H}, \mathrm{NH}){ }^{13} \mathrm{C}$ NMR $(50 \mathrm{MHz}$, $\left.\mathrm{CDCl}_{3}\right): \delta 113.0 .116 .5 .118 .0 .119 .6 .120 .4,120.8,122.3$, 124.0. 126.4. 127.8, 128.4,130.9. 138.2. 147.8; IR (KBr): $v_{\max } 3425.2923 .2852,1642,1561,1420.1244 .1008,878$. $744,592 \mathrm{~cm}^{-1}$; ESI-MS: $m / z: 294\left(\mathrm{M}^{+}+1\right)$.

3n: 2,5-Dichloro-3-(1-methyl-1H-indol-3-yl)benzene1,4-diol: Solid, m.p: $146^{\circ} \mathrm{C} ;{ }^{1} \mathrm{H}$ NMR (200 MHz. CDCl $) ; \delta$ $3.80(\mathrm{~s}, 3 \mathrm{H}) .5 .30$ (brs, 2H. OH). 7.05 (d, $J=1.8 \mathrm{~Hz} . \mathrm{lH}$ ), 7.10-7.45 (m. 5H): ${ }^{13} \mathrm{C}$ NMR $\left(50 \mathrm{MHz} . \mathrm{CDCl}_{3}\right): \delta 11.6$, $107.8,110.2$. 115.4. 118.7. 119.7. 120.2, 120.5. 121.4, 124.7, $127.3,130.4,136.8,146.3,146.9$. IR $(\mathrm{KBr}): v_{\max } 3459$. 2921. 2852. 1615, 1433. 1378. $1129,853.736 \mathrm{~cm}^{-1}$. ESIMS: $m / z: 308\left(\mathrm{M}^{-}+1\right)$

Acknowledgments. KSS. TSY and KPL thank CSIR. New Dellhi for the award of fellowship.

\section{References and Notes}

1. (a) Arai. K: Yamamoto. Y. Chem. Pharm. Bull. 1990. 38. 2929 (b) Kaji. A.: Saito. R.: Nomura. M.: Miyamoto. K.: Kiriyama. N. Biol. Pham. Bull. 1998. 21, 945 .

2. (a) Brewer. D; Jerram, W: Taylor. A. Can. J Microbiol. 1968. 14. 861. (b) Sekita, S. Chem. Pham. Bull 1983. 31. 2998. (c) Kaji. A.: Saito. R.: Hata. Y.: Kiriyama. N. Chem. Phom. Bull 1999. 47. 77.

3. (a) Arai. K.: Shimizu. S.: Taguchi. Y.: Yamamoto. Y. Chent. Pharn. Bull. 1981. 29. 991. (b) Shimizu. S.: Yamamoto. Y: Koshimura, S. Chem. Pham. Bull. 1982, 30, 1896. (c) Kaji. A.; Iwata. T.: Kiriyama, N.: Wakusawa, S.: Miyanoto, K. Chem. Pham Bull 1994, 12. 1682 .

4. (a) Alvi. K. A.: Pu. H.: Luche. M.: Rice. A.: App. H.: McMahon1. G.: Dare. H.: Margolis. B. J. Amitiot 1999. 52 .215. (b) Kaji. A.: Saito. R.: Nomura. M.: Miyamoto. K.: Kiriyama. N. Anficancer Res. $1997,17,3675$.

5. Zhang. B.: Salituro, G; Szalkowski. D.; Li. Z:: Zhang, Y.; Royo. I.: Vilella D.: Diez. M. T.: Pelaez, F.: Ruby. C.: Kendall. R. L. Mao. X.: Griftinl. P.: Calaycay. J.: Zierath. J. R.: Heck. T. V.: Stnith. R. G.: Moller. D. E. Science 1999.284. 974.

6. (a) Mohlau. R.: Redlich. R. Bet Disch. Chent. Ges. 1911. H. 3605. (b) Bu'Lock. J. D.; Harlev-Mason. J. J. Chem. Soc. 1951. 703. (c) Maiti. A. K.: Bhattachary, P. J. Chem. Res. (S) 1997. 424. (d) Yadav, J. S.: Reddv, B. V. S.: Swamy. T. Tetrahedron Lett 2003. 44. 9121 . (e) Yadav. J. S.: Reddy. B. V. S.: Swany. T. Symesis 2004. 1. 106. (f) Pirung. M. C.: Park. K.: Li. Z. Org. Lett. 2001. 3. 365. (g) Pirrung. M. C.: Deng. L.: Li. Z.: Park. K. J. Org. Chem. 2002.67,8374

7. (a) Kappe, C. O. Angew: Chem. Int. Ed 2004, 43, 6250. (b) Wathey. B.: Tiemey. J.: Lidstrom. P.: Westman. J. Drug Discoveny Todov 2002. 7. 373. (c) Lidstrom. P.: Tierney. T.: Wathey. B.: Westiman. T. Tetrahedron 2001. 57.9225.

8. (a) Lew. A.: Krutzik. P. O.: Hart. M. E.: Chamberlin. A. R. J. Comb. Chem 2002. 4. 95. (b) Perreux, L.: Loupy. A. Tetolhedrom 2001. 57. 9199. (c) Lidstrom, P; Tierney, J.; Wathey, B.; Westman, J. Tetrahedron $2001,57.9225$. 